\title{
On Innovation of College Psychological Health Education in the New Media Era
}

\author{
Xiaoyan Ding* \\ School of Mechanical and Electronic Engineering \\ Wuhan University of Technology \\ Wuhan, P.R.China
}

\begin{abstract}
In the new media era, the psychological condition and behavioral features of contemporary college students are highly distinctive. In this paper, the college students' psychological health education in the new media era is comprehensively analyzed and the innovation of college students' psychological health education is specifically put forward. Colleges and universities should focus on the innovation in the concept, content and form as well as the mechanism of psychological health education so as to improve the education effects.
\end{abstract}

Keywords-the new media; college students; psychological health education; innovation

\section{INTRODUCTION}

In the new media era, the spread of knowledge and information has stepped into a new stage at an unprecedented speed due to the rapid development of the network, which exerts a certain impact on contemporary college students' thoughts and ideology. It has become an important and urgent task to make effective use of new media in college ideological and political education service and promote the education quality to a higher level. In recent years, many domestic scholars of high school education have done a great deal of research on college ideological and political education in the new media era. Professor Ji Haiju published Deconstruction and Remodeling of College Ideological and Political Education in the New Media Era in 2014 with systematical elaboration.[3] Professor Chi Guiyuan published Research on Contemporary College Students' Ideology and Politics Education from the Perspective of New Media in 2014.[2]

However, college psychological health education, which is an indispensable and significant part of college ideological and political education, is less systematically researched. The psychological state of contemporary college students has distinctive features and it has brought new difficulties and challenges to the college students' psychological health education. It is also a significant part of the ideological and political education work of colleges and universities to strengthen the all-round development of college students under the new situation. Therefore, it is of great practical importance to actively explore the innovative path of psychological health education for college students in the new media era.

\section{CHARACTERISTICS OF COLLEGE STUDENTS Psychological State IN THE NEW MEDIA ERA}

College students are active advocates of new media. With the influence of new media on college students' thoughts and behaviors, the psychological state of college students presents new features. The contents and ways of communication of the new media have a great influence on college students' study and life.[7]

\section{A. Emphasis on Intellectual plurality and discourse power}

Contemporary college students are the main users of the new media. The vast amount of information brings many conveniences to their life, study and interpersonal relationship. The information dissemination of new media enables them to learn the news and information all around the world anytime and anywhere. They can also participate in the process of communication and interaction with the world. Convenient access to information has inspired their imagination and creativity and developed their thinking ability, which broadens their horizons to a great extent and results in Intellectual plurality of college students. In the new media era, college students pay more attention to themselves than ever before. They emphasize their discourse power and are more likely to express their opinions, have a stronger awareness of human rights, and pursue integrity and social justice.

\section{B. Highlighted contradictions of real and virtual interaction}

As the main group of Internet application, the college students are more able to choose, express and spread information in the open network platform. Every student has equality and autonomy.[8] In addition, some of the unfavorable moods in their life or study of college students can be resolved through the multimedia network, which brings the physical and mental relaxation and promotes their psychological health development.

However, the platform and space which the new media provides is a relatively virtual interactive world. Excessive reliance on new media makes it hard for college students to regulate and balance their psychological health status. In the virtual world, college students can express their ideas freely. Various forms of entertainment can also lead them to Internet addiction and unwillingness to face reality. The virtual interaction and communication make some college students get used to avoiding real interpersonal communication, and be solitary and live in their own inner circle.[6] 


\section{Indefinite perception of life values}

Virtual interaction in the network society and the relatively weak interpersonal relationships in the real world have exerted strong shock and impact on college students' value orientation, which leads to a deficient understanding of significance and value of life. College students would re-examine the meaning of such issues as life dignity, life value and meaning of life. Due to the uncertainty of value orientation, there will be inevitably different results. When taking a positive attitude, they are able to face difficulties actively. While taking a negative attitude, they are more likely to feel empty and confused, lose the ideal and goal of life, which results in serious psychological problems or even extreme behaviors.

\section{The PREDICAMENT OF COLlege PSYCHOLOGICAL Health Education in the New Media ERA}

In the new media era, information resources turn more complicated in the new media era. This has a significant influence on the development of the psychological health of college students and has brought new challenges and difficulties to college psychological health education.

\section{A. Continuously weakening function and influence of college psychological health education}

In the new media era, the network convenience makes the latest knowledge within reach, which has not only brought a great challenge to the knowledge wealth of college psychological health educators but also weakened the function and influence of college psychological health education. Although college students have obviously enhanced awareness of self-regulation and increasing acceptance of psychological counseling, they have weakened enthusiasm to participate in related courses or lectures due to the advanced access to network information in various aspects. They are more likely to find information resources suitable for themselves from the Internet. It inevitably results in weakening impact and guidance of psychological health educators in colleges and universities on the development of students' mental health. In the meantime, also the reliance of contemporary college students on educators has also been weakened.

\section{B. Deficient developmental psychological health education}

In recent years, increasing importance has been attached to students' psychological health education in colleges and universities. Increasing inputs have been given to timely psychological intervention to help students resolve the mental contradiction and conflict in academic, emotional, interpersonal, career planning and other aspects. Many college students have established the concept of timely help through developmental psychological education. However, in comparison, the current college psychological health education is mainly remedial, not developmental. The enthusiasm and initiative of the students as individuals are likely to be ignored while too much attention is paid to the psychological problems of students.[4] Psychological health education should advocate more preventive education, cultivate students' good psychological quality, make it possible for students to adjust their mentality according to the ever-changing situation and rationally know themselves and promote their own free and comprehensive development."

\section{Deficient combination of education and new media}

Some psychological health educators in colleges and universities have certain defects in teaching research and management, especially lacking awareness of the combination of psychological health education with new media to strengthen education effect.

In the era of new media, the psychological changes of college students are relatively complex due to the vast amount of information access. It is much more difficult to master the law of the students' psychological development, which affects the effectiveness of psychological education. At present, the teaching method of college psychological health education is in the monotonic form with the deficient appliance of modern network techniques. It is unattractive and hard to meet the psychological needs of university student for the focus on new media.

\section{The INNOVATION OF COLLEGE PSYCHOLOGICAL HEALTH EDUCATION IN THE NEW MEDIA ERA}

\section{A. Innovation in the concept of college psychological education}

Colleges and universities should change the educational concept from the traditional type to solve the problem into developmental preventive education. It fully reflects the enthusiasm and subjectivity of college students as the object of education and avoids stepping into a morbid psychological orientation featuring mental disease prevention and treatment. The education task, which is traditionally used to impart psychological knowledge and deal with psychological problems, should be transformed into the cultivation of people with noble souls and firm values. Value orientation of college psychological education should be highlighted so as to stimulate students' psychological potential.

The moral educational function of college psychological education, which runs through the whole college study and life, should be given full play. The students' subject of consciousness should be improved. Experiential life education should be integrated into college psychological education. Students should be guided to make full use of external conditions for self-education and psychological adjustment, which is a long way to creating the educational atmosphere of self-education, self -adjustment as well as self-training.[10] Students should learn how to actively make use of new media and improve their media literacy. The students should have the ability of healthy media criticism and be able to distinguish the vast amounts of network information resources. Full use of media resources should be made to perfect themselves to avoid the negative effects of network information.

\section{B. Innovation in the content and form of college psychological health education}

Text heads organize the topics on a relational, hierarchical basis. For example, the paper title is the primary text head because all subsequent material relates and elaborates on this one topic. If there are two or more sub-topics, the next level head (uppercase Roman numerals) should be used and, conversely, if there are not at least two sub-topics, then no subheads should be introduced. Styles named "Heading 1," 
“Heading 2," “Heading 3," and "Heading 4" are prescribed. With network multimedia technology, colleges and universities should improve the methods of psychological health education. The traditional cramming educational forms such as psychological lectures and courses should be changed into a more integral means both in class and out of class. Targeted mental health education curriculum should be provided according to different characteristics of the college students' psychological problems.[9] A dynamic combination should be set up covering psychological education seminar, psychological consulting room, group counseling and various activities organized by different student communities. Individual education should also be available for particular students or groups of mental confusion or problems. By all means, the content of college psychological health education should be enriched and the diversification of education activities should be enhanced so as to broaden the educational channel.

The role of mass media to promote college psychological health education should be given full play. The publicity function of the media can be favorably applied to convey methods and measures of improving the quality of psychological education.[1] In addition, in the era of rapid Internet development, the network psychological health education can also be actively carried out. For example, colleges and universities can set up the network platform of online psychological health education. It can, to a large extent, protect college students' privacy of psychological problems and enable them to get direct assistance through the network.

\section{Innovation in the mechanism of college psychological health education}

In the new media era, colleges and universities need to construct the education mode which conforms to the physical and mental development characteristics of contemporary college students, which promotes their healthy growth and comprehensive development. A Five in One Psychological Health Education Mode should be set up covering psychological health education curriculum, psychological health education activities, psychological counseling, psychological crisis intervention and psychological investigation and research. Psychological health curriculum plays the main role to help students correctly understand the law of psychological development and master the necessary mental health knowledge. Psychological health education activities of various forms promote students to improve their comprehensive quality and achieve coordinated development. Psychological counseling aims at helping students solve problems. The intervention work of psychological crisis is to prevent the problems from happening, focusing the students' safety and ensuring the healthy and smooth growth of them. Carrying out psychological investigation and research contributes to timely understand and grasp students' psychological conditions and characteristics, and enhance the pertinence and effectiveness of psychological health education in colleges and universities.

\section{CONCLUSION}

The new media can meet the requirements of college students for entertainment and communication. They lay more emphasis on their intellectual plurality and discourse power. However, the virtual nature interactive features of new media is highly likely to trigger a crisis of confidence and personality disorder.[5] There are more highlighted contradictions of real and virtual interaction for college students. Moreover, deficient rational knowledge of new media will lead the college students to excessive dependence on new media and indefinite perception of life values. All these elements have brought great challenges and predicament of college psychological health education in the new media era, including continuously weakening function and influence of college psychological health education, deficient developmental psychological health education as well as the deficient combination of education and new media. For college psychological health educators, the innovation of college psychological health education in the new media era should seek out. Rethinking should be raised not only in the concept, the content and form of college psychological health education but also in the overall education mechanism. With all-around efforts and consistent innovation integrating the influence of the new media era to college psychological health education, more targeted and effective psychological health education result can be realized.

\section{REFERENCES}

[1] Cai Yamin. Discussion on Innovation Path of College Students' Mental Health Education[J]. The Party Building and Idealogical Education in Schools, 2016,(2):90-91 (In Chinese)

[2] Chi Guiyuan. Research on Contemporary College Students' Ideology and Politics Education from the Perspective of New Media[M]. Beijing: China Social Sciences Press, 2014: 3 (In Chinese)

[3] Ji Jumei. Deconstruction and Remodeling of College Ideological and Political Education in the New Media Era[M]. Nanjing: Southeast University Press, 2014: 1 (In Chinese)

[4] Luo Xiaolu. The Status Quo and Countermeasures of College Students' Mental Health Education[J]. Educational Research, 2018, 39(1):112118(In Chinese)

[5] Ma Yulong. Mental Health Education of Students in the New Media Era[J]. China Educational Technology of Equipment, 2010,(10):198(In Chinese)

[6] Wang Qin. Mental Health Education of College Student[M]. Wuhan: Wuhan University of Technology Press, 2014: 21-25 (In Chinese)

[7] Wang Xuejian, Liu Qiang. The New Media and College Ideological and Political Education[M]. Beijing: People's Publishing House, 2012: 1620 (In Chinese)

[8] Yang Hai, Wang Xiaoxiao. Research on College Psychological Health Students in the New Media Era[J]. The Party Building and Idealogical Education in Schools, 2015, (12):82-83(In Chinese)

[9] Zhang Shu. Analysis of College Students' Psychological Health Education Method in the New Media Era[J]. Journal of Zhengzhou Railway Vocational and Technical College, 2017, 29(3): 88-89(In Chinese)

[10] Zhang Youli. Education Model of Developmental Mental Health in Colleges and Universities Based on Students' Subjectivity[J]. Jiangsu Higher Education, 2014,(6): 141-142(In Chinese) 